Jurnal Homepage: http:/journal2.um.ac.id/index.php/jaa (p-ISSN: 2087-9695; e-ISSN: 2580-1015)

\title{
Apakah bumdes sudah taat pada good governance?
}

\author{
Nindya Krismonica Titania ${ }^{1}$, Intiyas Utami ${ }^{1}$ \\ ${ }^{1}$ Universitas Kristen Satya Wacana, Jl. Diponegoro No. 52-60, Salatiga, Indonesia
}

\begin{abstract}
Diterima: 4 Juni 2020
Direvisi: 1 Oktober 2020

Disetujui: 4 Oktober

2020
\end{abstract}

\section{Korespondensi:}

Nindya Krismonica Titania

NindyaKT20@gmail.com

DOI:

http://dx.doi.org/10.17977/

um004v8i12021p77

\begin{abstract}
The aim of this study is to observe the practice of BUMDes' governance in the perspective of good governance government. In theoretical framework, BUMDes should be managed by concept of good governance government. However, the core problem relates to whether the BUMDes has been properly managed with the concept of good governance government or not. This study used interpretive paradigm with case study method. The research data was collected from informant involved in the management and activities of BUMDes. The result of this study shows that a rural fund has been considered as an BUMDes' initial capital. Additionally, this research also reveals that: people attendance in a rural meeting has been considered as a form of participation; rural website and whatapp group have reflected transparency; ineffective accounting practice has represented a poor financial accountability.

Keywords: Good Governance Government, Participation; Transparency; Accountability; BUMDes
\end{abstract}

\begin{abstract}
Abstrak
Penelitian ini bertujuan untuk memahami tatakeloa Badan Usaha Milik Desa (BUMDes). Secara teoritis BUMDes sehasusnya dikelola dengan konsep good governance government. Namun, fokus permasalahan terletak pada pengelolaan BUMdes yang sesuai atau tidak sesuai dengan konsep tersebut. Penelitian ini menggunakan paradigma intepretif dengan metode studi kasus. Data penelitian bersumber dari informan yang terlibat dan terkait dalam pengelolaan dan kegiatan BUMDes. Temuan penelitian ini antara lain dana desa sebagai modal awal BUMDes, kehadiran masyarakat dalam musyawarah desa dimaknai sebagai bentuk partisipasi, keberadaan website desa dan grup whatsapp sebagai bentuk ransparansi, dan belum berjalannya praktik akuntansi sebagai bentuk akuntabilitas keuangan.

Kata Kunci: Good Governance Government; Partisipasi; Transparansi; Akuntanbilitias; BUMDes
\end{abstract}

\section{PENDAHULUAN}

Desa merupakan komunitas terkecil suatu negara yang mempunyai hubungan dengan kelompok masyarakat dan secara langsung dapat menyentuh kebutuhan masyarakat. Desa menggambarkan unit komunitas hukum yang memiliki batasan wilayah untuk peraturan daerah, dan kepentingan masyarakat yang didasarkan pada inisiatif masyarakat, hak asal, hak tradisional yang dihormati oleh sistem pemerintah (Undang-Undang No. 6 Tahun 2014). Pertumbuhan ekonomi di Indonesia juga didukung oleh adanya ekonomi desa sebagai upaya untuk melakukan pembangunan di daerah tertinggal yang bersifat partisipatif sehingga pemerintah mengeluarkan Kebijakan Dana Desa (Mustanir \& Abadi, 2017). Desa di Indonesia masih banyak yang mengalami kemiskinan meski perekonomian ekonomi Indonesia sudah mulai membaik saat ini. Sehubungan dengan kondisi tersebut, pemerintah desa harus mampu mendorong masyarakat untuk ikut mengembangkan ekonomi desa.

Pemerintah pusat mulai memberikan perhatian lebih terhadap perkembangan ekonomi desa dengan menaikan anggaran dana desa setiap tahun. Pada tahun 2019, dana desa mengalami peningkatan sebesar Rp70 triliun yang pada tahun sebelumnya mendapat anggaran sebesar Rp60 triliun (Kompas, 2019). Sumber dana desa berasal dari APBN (Anggaran Pendapatan dan Belanja Daerah dimana anggaran dana desa mengalami peningkatan untuk mendukung pembangunan desa (Undang-Undang No. 6 Tahun 2014). Dalam Peraturan Menteri Dalam Negeri Nomor 113 Tahun 2014, upaya untuk mengimplementasikan anggaran tersebut diharapkan dapat memenuhi prinsip dana desa yang transparan, akuntabel, dan partisipatif. 
Tata kelola organisasi desa di Indonesia masih belum cukup optimal karena kualitas dari sumber daya manusia dapat menjadi salah satu penghambat dalam pembangunan desa (Triani \& Handayani, 2018). Salah satu komponen dari tata kelola yang baik adalah terwujudnya prinsip akuntabilitas. Akuntabilitas dalam suatu kelembagaan pemerintah desa sangat penting yang berarti bahwa lembaga tersebut harus dapat mempertanggungjawabkan kegiatan organisasi desa yang menggunakan anggaran dana desa (Nahruddin, 2014).

BUMDes merupakan salah satu usaha pemerintah untuk mendorong peningkatan ekonomi desa. Anggaran dana desa yang digunakan untuk mendirikan BUMDes harus dapat dipertanggungjawabkan oleh pemerintah desa dengan selalu melakukan sosialisasi terhadap pencairan anggaran dana desa sebagai wujud akuntabilitas (Ismail et al., 2016). BUMDes merupakan organisasi desa yang digunakan untuk dapat menyejahterakan ekonomi desa dan harus memiliki tata kelola yang baik (Kusumawanti et al., 2017).

Carter, Burritt, dan Pisaniello (2013) menyatakan bahwa penerapan kebijakan dana desa mempunyai pengaruh positif terhadap pengelolaan dana desa dan keefektifan pada program pembangunan desa. Pelaksanaan BUMDes dapat dikatakan belum efektif dalam memberikan kontribusi kepada masyarakat bila pola pemanfaatan dana BUMDes belum dikelola dengan baik (Prasetyo, 2016). Hal ini didukung oleh penelitian Triani dan Handayani (2018) yang menyatakan bahwa pembangunan desa terhambat karena faktor kualitas sumber daya manusia. Penghambat pengelolaan BUMDes dapat terjadi karena aparat desa tidak dapat secara akuntabel mengemukakan pengalokasian anggaran dana desa dikarenakan sumber daya manusia yang rendah. Kondisi tersebut memengaruhi tata kelola desa.

BUMDes mempunyai karakteristik social enterprise atau bisa juga dikatakan sebagai lembaga bisnis yang didirikan untuk dapat menyelesaikan masalah sosial yang menyebabkan BUMDes harus mempunyai prinsip akuntabel (Widiastuti et al., 2019). Karakter social enterprise menjadikan BUMDes tidak dapat lepas dari pengaruh lingkungan sosial. Organisasi sangat membutuhkan peran penting pemangku kepentingan dalam pengambilan keputusan untuk kelangsungan hidup usaha. Pemangku kepentingan terdiri dari pemilik perusahaan, investor, komunitas, pemerintah, dan karyawan (Lindawati \& Puspita, 2015).

Di wilayah Jawa Tengah, terdapat kabupaten yang memiliki 19 kecamatan dan 267 desa. Desa yang menjadi salah satu desa pertama memiliki BUMDes berupa pasar kuliner dan persewaan ruko serta mendapat pujian dari kepala Dinas Kesehatan sebagai desa pertama yang mengalokasikan sebagian keuntungan dari hasil pendapatan BUMDes untuk dialokasikan ke iuran BPJS kesehatan warga yang kurang mampu (Suaramerdeka, 2018). Desa yang memiliki keunggulan dalam alokasi keuntungan BUMDes ke bidang kesehatan berpotensi mengalami hambatan dalam mewujudkan akuntabilitas. Tujuan dari penelitian ini adalah untuk lebih memahami tata kelola BUMDes dalam perspektif good governance government. Sehubungan dengan itu, kemampuan BUMDes dalam mewujudkan tata kelola yang baik perlu dieksplorasi.

\section{METODE}

Penelitian ini menggunakan metode kualitatif dengan paradigma interpretif. Paradigma intepretif merupakan cara untuk mencari informasi mengenai peristiwa sosial atau budaya berdasarkan pada perspektif narasumber (Muslim, 2016). Sesuai dengan tujuan penelitian, maka studi kasus (Yin, 2003) dipilih sebagai metode penelitian karena strategi tersebut dapat digunakan untuk memahami bagaimana praktik tata kelola BUMDes. Situs penelitian adalah Desa X wilayah Jawa Tengah. Desa $\mathrm{X}$ dipilih karena menjadi desa pertama yang mengalokasikan sebagian keuntungan BUMDes ke dalam iuran BPJS kesehatan warga. Hal ini menjadi pertimbangan bahwa BUMDes tersebut telah berhasil mendapatkan keuntungan yang bisa dimanfaatkan oleh warga desa. Data penelitian ini adalah hasil wawancara dari para informan yang terlibat dan terkait dengan kegiatan dan operasionalisasi BUMDes. Para informan trsebut antara lain Bapak YJ (Kepala Desa), Bapak BK (Bendahara BUMDes), Bapak AS (Anggota BUMDes), Bapak S (Ketua RT), Bapak M dan K (masyarakat). Adapun teknik analisis data menggunakan teknik tematisasi data (Myers, 2009).

\section{HASIL DAN PEMBAHASAN}

Desa yang digunakan dalam penelitian ini terletak di wilayah Jawa Tengah dengan total jumlah penduduk 3.560 jiwa yang terdiri dari penduduk laki-laki sebanyak 1.685 dan perempuan sebanyak 1.875 jiwa. Pendidikan masyarakat desa yaitu terdapat 218 penduduk tidak bersekolah atau bersekolah sampai tingkat SD tetapi tidak tamat. Selanjutnya, penduduk yang tamat SD sebanyak 1174 orang; tamat SMP sebanyak 912 orang dan tamat SMA sebanyak 746 orang. Penduduk yang menyelesaikan 
pendidikan D1/D2 sebanyak 34 orang; D3 sebanyak 98 orang; dan S1 sebanyak 106 orang. Mayoritas pekerjaan masyarakat yaitu petani dan peternak sekitar 1.455 orang dan berbagai profesi lainnya tetapi dengan persentase yang kecil. Selain menjadi pusat pemerintahan desa dan pusat pasar tradisional, desa ini juga menjadi salah satu desa yang menjadi desa unggulan di kecamatan karena memiliki sejumlah prestasi di bidang olahraga dan kesenian. Desa ini juga merupakan desa pertama yang memiliki BUMDes. BUMDes ini didirikan untuk meningkatkan perekonomian desa, meningkatkan pendapatan asli desa, meningkatkan pengelolaan potensi desa sesuai dengan kebutuhan masyarakat desa.

\section{Musyawarah Desa (Musdes): Langkah Awal Pendirian BUMDes}

Untuk memajukan perekonomian desa, salah satu cara yang dapat digunakan adalah dengan didirikannya Badan Usaha Milik Desa (BUMDes). BUMDes merupakan salah satu bentuk implementasi dari pengelolaan dana desa yang mengelola potensi kemandirian desa dengan berbagai macam kegiatan ekonomi secara swadaya masyarakat dan gotong royong (Ismail et al., 2016). Dalam hal ini, peran partisipasi masyarakat sangat dibutuhkan dalam pengambilan keputusan yang diharapkan secara bertahap dapat mewujudkan tujuan desa sesuai dengan kebutuhan masyarakat. Dalam proses perencanaan pembentukan BUMDes, musyawarah desa (musdes) menjadi salah satu wadah dalam mensosialisasikan program kerja dari pemerintah desa. Seperti yang dikemukakan oleh Bapak YJ selaku kepala desa:

"Pembentukan BUMDes itu diawali dengan diadakannya sosialisasi kepada masyarakat. Sosialisasi ini dilakukan dengan Musdes yang merupakan forum permusyawaratan yang diikuti oleh Badan Permusyawaratan Desa, Pemerintah Desa, dan sebagian masyarakat desa. Sosialisasi ini sangat diperlukan untuk menjelaskan kepada masyarakat apa itu BUMDes dan lebih untuk membangun relasi yang baik antara pemerintah desa dengan masyarakat. Langkah ini sangat penting dalam proses pembentukan BUMDes, dengan mengikutsertakan masyarakat sejak awal agar masyarakat paham dan percaya dengan program pemerintah desa”.

Hal ini juga mendapat tanggapan yang sesuai dengan pendapat Bapak S selaku ketua RT: "Masyarakat memang sudah seharusnya terlibat dalam setiap perencanaan desa. Seperti halnya dalam perencanaan pembentukan BUMDes melalui musdes ini masyarakat harus terlibat karena menyangkut kepentingan bersama. Banyak sekali warga yang antusias dengan adanya pembentukan BUMDes in"'.

Bapak $\mathrm{S}$ juga mengatakan bahwa warga aktif berpartisipasi dalam mengikuti musdes yang diadakan di balai desa. Hal tersebut didukung dengan pernyataan:

"Warga yang mengikuti musdes lumayan banyak, ada sebagian yang ikut rembugan bersama kepala desa dan ada juga yang menunggu di luar".

Dengan adanya musdes yang mengikutsertakan masyarakat langsung dalam kegiatan, perencanaan dan penggunaan dana desa yang dialokasikan untuk BUMDes diharapkan sesuai dan tepat sasaran dengan keperluan masyarakat desa. Hal ini juga disampaikan oleh Bapak YJ sebagai berikut:

"Musdes punya banyak manfaat bagi masyarakat mbak. Dengan adanya musdes ini biasanya lebih membuat hubungan antara perangkat desa dan masyarakat semakin harmonis. Musdes seperti ini juga bisa digunakan untuk memikirkan bersama bagaimana mengelola desa agar menjadi lebih baik kedepannya, dan masyarakat juga bisa belajar tentang bagaimana menghargai pendapat orang lain dan menekan kepentingan pribadi guna kepentingan bersama".

Perencanaan pembentukan BUMDes sudah dilaksanakan sesuai dengan undang-undang yang berlaku serta telah melibatkan masyarakat dalam setiap perencanaan. Partisipasi atau keterlibatan masyarakat sangat diperlukan dalam setiap perencanaan yang dibuat oleh desa. Pengambilan keputusan untuk kepentingan desa tidak dapat lepas dari peran serta masyarakat. Menurut penelitian Batubara (2006), partisipasi dibangun atas dasar kebebasan dalam berasosiasi dan berbicara serta dapat berpartisipasi secara konstruktif. Perencanaan pembentukan BUMDes mendapat respon yang sangat baik dari masyarakat desa. Pendirian BUMDes berupa ruko dan kulineran telah sesuai dengan kebutuhan serta potensi yang ada pada desa. Hal ini selaras dengan pernyataan Ridlwan (2014) yang menyatakan bahwa salah satu tujuan dari perencanaan pembentukan BUMDes adalah mewujudkan pembangunan desa yang sesuai dengan kebutuhan masyarakat dan keadaan desa. Untuk mewujudkan BUMDes yang taat terhadap good governance, pemerintah desa telah memberikan kebebasan kepada masyarakat dalam memberikan pendapat untuk menuju BUMDes. 


\section{Dana Desa: Modal Awal BUMDes}

Undang-Undang No. 6 Tahun 2014 pasal 87 menyatakan bahwa desa dapat mendirikan BUMDes dengan menggunakan dana desa yang dapat dikelola dengan semangat kekeluargaan dan gotong royong. Sebagian modal BUMDes yang dimiliki oleh desa melalui penyertaan secara langsung yang berasal dari kekayaan desa dan telah dipisahkan untuk mengelola aset, jasa pelayanan, dan usaha lainnya untuk kesejahteraan masyarakat desa. Bapak YJ menjelaskan bahwa sumber dana pelaksanaan kegiatan BUMDes berasal dari dana desa melalui beberapa tahapan dalam penyaluran dana untuk kegiatan desa. Berdasarkan hasil wawancara, Bapak YJ menjelaskan bahwa:

"Penyaluran dana yang dilakukan itu ada dua tahapan yang pertama adalah dari Rekening Kas Umum Negara (RKUN) ke Rekening Kas Umum Daerah (RKUD). Tahap yang kedua dari RKUD ke Rekening Kas Desa (RKD). Periodisasi penyaluran dana desa dari RKUN ke RKUD dilakukan sejak bulan Januari sampai bulan April. Di minggu kedua bulan April itu, tahapan pertama dari RKUD ke RKD sebesar 40\%. Tahap keduanya dilakukan pada minggu kedua bulan Agustus ditransfer lagi ke RKD sebesar 40\%. Tahapan ketiga dilakukan pada minggu kedua bulan Oktober ditransfer kembali sebesar 20\%".

Selain sumber dana yang digunakan dari dana desa, kegiatan yang dilakukan dalam pelaksanaan BUMDes juga dilakukan secara mandiri oleh masyarakat. Hal ini juga disampaikan oleh Bapak YJ, yaitu:

"Kegiatan pelaksanaan BUMDes sebisa mungkin dikerjakan sendiri oleh warga desa

Kebonan. Hal ini dilakukan karena pemerintah desa ingin warga dapat berpartisipasi dalam mewujudkan pembangunan desa".

Penjelasan yang diberikan oleh Bapak YJ mengenai pelaksanaan kegiatan BUMDes yang dilakukan secara mandiri diperkuat oleh Bapak AS yang menyatakan bahwa:

“Dalam kegiatan pembangunan BUMDes memang dikerjakan secara mandiri oleh warga, hanya beberapa kegiatan yang tidak bisa dilakukan seperti bangun ruko dan bangun taman karena harus pakai tukang bangunan dan tukang yang ahli dalam taman. Kecuali jika dirasa masyarakat bisa melakukan sendiri seperti memasang stand makanan (kulineran) akan kami lakukan secara bersama- sama”.

Salah satu warga yang ikut serta dalam pelaksanaan pembuatan BUMDes juga menyatakan bahwa semua kegiatan dilakukan sendiri oleh warga. Dalam wawancara, Bapak S mengungkapkan:

"Kegiatan di desa X ini kalau masyarakatnya mampu melakukan sendiri pasti dilakukan sendiri. Dana dari pemerintah kan berupa uang mbak, jadi setiap desa itu diharuskan bisa mengelola dana itu sendiri, maka dari itu ada tim pengelola kegiatan untuk mengurusi keuangannya".

Hal ini disetujui oleh Bapak $M$ yang merupakan warga desa yang juga ikut membantu dalam pelaksanaan pembangunan BUMDes. Berdasarkan hasil wawancara, Bapak M mengungkapkan:

"Pembangunan BUMDes dilakukan dengan sistem gotong royong bersama-sama. Beberapa warga ikut membantu dalam proses pembangunan BUMDes, demi pembangunan desa yang lebih maju semua dilakukan bersama-sama”.

Selain pembangunan BUMDes, terdapat pembangunan desa yang lain seperti pembangunan jalan, dan pembangunan selokan juga dilakukan oleh warga sendiri. Seperti yang diungkapkan oleh Bapak M yang juga membantu dalam pembuatan selokan di desa Kebonan:

"Saya ikut membantu saat pembuatan selokan, semua kegiatan desa memang sudah seharusnya dilakukan oleh warganya sendiri, karena memang untuk kepentingan bersama".

Pelaksanaan pembangunan BUMDes sangat menjunjung kemandirian dari warga desa. Sebagai langkah dalam mewujudkan BUMDes yang taat akan good governance government, Bapak YJ selaku kepala desa selalu melibatkan masyarakat di setiap kegiatan yang dilakukan. Seperti halnya dalam pembangunan BUMDes, semua kegiatan diupayakan untuk dikerjakan sendiri oleh masyarakat dengan gotong royong bersama. Hal tersebut dilakukan untuk menuju desa yang mandiri dan juga dapat menghemat biaya. Selaras dengan penelitian Agunggunanto dan Kushartono (2016) yang mengatakan bahwa desa mandiri merupakan desa yang dapat memenuhi kebutuhan sendiri dan apabila mendapat bantuan pemerintah maka bantuan tersebut hanya bersifat perangsang. UndangUndang No. 4 Tahun 2015 menyatakan bahwa kewajiban pelaksanaan operasional harus melaksanakan dan mengembangkan BUMDes agar menjadi lembaga yang dapat melayani kebutuhan ekonomi dan dapat menjadi pelayan umum masyarakat desa. 


\section{BUMDes dan Good Governance Government}

Good governance government tidak dapat berjalan dengan baik apabila tidak melibatkan kerjasama antar pemangku kepentingan. Pelaksanaan good governance government yang baik harus mengutamakan prinsip partisipasi, akuntabilitas, dan transparansi yang memerlukan idealisme yang kuat dari para pengurus BUMDes. Pengelolaan BUMDes pemerintah desa harus dapat memberikan transparansi kepada masyarakat mengenai kegiatan yang dilakukan. Transparansi merupakan sebuah informasi yang dapat diakses oleh semua orang dan dapat dimengerti oleh semua pihak dalam organisasi tersebut. Berdasarkan hasil wawancara dengan Bapak YJ, pengelolaan BUMDes dalam menyediakan informasi dilakukan melalui musyawarah desa dan pelaporan pertanggungjawaban di akhir tahun. Bapak YJ mengatakan bahwa:

"Musyawarah desa wajib dilakukan minimal satu tahun sekali, untuk pelaksanaannya musdes dibiayai oleh Anggaran Pendapatan dan Belanja Daerah (APBD). Musdes juga melibatkan warga desa yang diundang secara resmi oleh pemerintah desa, biasanya seperti tokoh dari masyarakat atau warga desa yang mau ikut memang diperbolehkan".

Informasi tersebut juga dapat diakses pada website desa serta dapat diakses juga melalui grup whatsapp. Sesuai dengan penelitian yang dilakukan oleh Mansur (2017) yang menyatakan bahwa sistem layanan informasi desa di desa yang terletak di wilayah Provinsi Riau dapat diakses melalui media online atau website dengan tujuan untuk meningkatkan transparansi informasi. Pemanfaatan sistem layanan informasi desa itu dengan memanfaatkan media online yang dapat menyediakan berbagai informasi dari potensi desa, kegiatan desa sampai penyediaan informasi terkait dengan BUMDes. Hal ini juga disampaikan Bapak YJ sebagai berikut:

"Di desa ini juga terdapat website yang digunakan masyarakat untuk mempermudah dalam mencari informasi meskipun masih ada beberapa data yang belum komplit, serta telah dibentuk grup whatsapp agar masyarakat dapat secara langsung menyampaikan keluhan ataupun saran tanpa melalui prosedur yang susah".

Musyawarah desa yang diadakan bagi sebagian masyarakat ternyata dirasa kurang efektif, kecuali hanya untuk memenuhi aspek formal saja. Pernyataan ini disampaikan oleh Bapak S sebagai berikut:

"Ada beberapa masyarakat yang mengikuti musdes, tetapi hanya sekedar untuk memberikan dorongan serta motivasi pada anggota warga yang lain saja. Saya selalu dapat undangan dalam musdes yang diadakan pemerintah desa, tapi karena banyak masyarakat desa yang ikut berpartisipasi, biasanya malah tidak efektif karena jadi banyak yang hanya mengobrol sendiri di luar".

Hal ini menjadi salah satu faktor yang menghambat pemerintah desa dalam melaksanakan good governance government yang baik, bahwa partisipasi masyarakat desa dalam musyawarah desa belum terlaksana secara efektif. Peran pemerintah desa dan masyarakat sangat penting dan wajib dipenuhi dalam pengelolaan BUMDes. Keikutsertaan masyarakat sangat dibutuhkan dalam pengambilan keputusan yang digunakan dalam pengelolaan BUMDes. Dalam wawancara, Bapak S mengatakan bahwa:

"Komitmen antara pemerintah desa dan masyarakat sangat diharapkan dapat mengembangkan tingkat keikutsertaan masyarakat desa demi menuju desa yang lebih baik kedepannya".

Pengelolaan BUMDes juga berhubungan dengan prinsip akuntabilitas. Organisasi seharusnya memiliki kinerja yang tetap dan berkelanjutan agar pertanggungjawaban dapat dilakukan dengan transparan dan jujur. Dalam BUMDes Mandiri, proses akuntansi dalam pengelolaan BUMDes belum berjalan dengan baik. Hal ini disampaikan oleh Bapak BK sebagai berikut:

"Masalah akuntansi itu tugas dari bendahara, bendahara mencatat setiap pemasukan dan pengeluaran desa. Bendahara juga bertugas membuat laporan keuangan yang dapat dipertanggungjawabkan kedepannya. Berhubung BUMDes Mandiri ini baru berjalan sekitar satu tahun, jadi untuk laporan keuanganya masih dalam proses pembuatan".

Bentuk akuntabilitas atau pertanggungjawaban dapat direalisasikan dalam bentuk laporan pertanggungjawaban. BUMDes merupakan salah satu organisasi pelayanan masyarakat yang menjadi program prioritas pemerintah desa berdasarkan Peraturan Menteri Desa Pembangunan Daerah Tertinggal dan Transmigrasi No. 19 Tahun 2017. Faktor-faktor yang dapat menghambat pelaksanaan good governance government adalah dari anggota BUMDes tersebut. Hal ini dikonfirmasi oleh Bapak BK yang menyatakan: 
"Saya bukan lulusan dari akuntansi mbak, saya tadinya lulusan teknik informatika, untuk pembuatan laporan saya masih harus banyak belajar. Pak Kades juga selalu memberikan bimbingan agar lebih baik lagi dalam pembuatan laporan keuangan".

Berdasarkan hasil penelitian dari Kurniasih dan Wijaya (2017), rendahnya kinerja BUMDes di Wilayah Kabupaten Banyumas disebabkan oleh adanya ketidakmampuan dari pengelola dalam mencapai nilai efisiensi, efektivitas, ekonomi, responsivitas, dan pemberdayaan masyarakat. Dalam penelitian tersebut juga ditemukan bahwa bagian paling penting terhadap lemahnya kinerja BUMDes adalah bahwa BUMDes belum dikelola secara profesional. Transparansi dan akuntabilitas merupakan prinsip utama dalam pengelolaan suatu organisasi. Dasar dalam pengelolaan organisasi harus terbuka dan transparan sehingga terdapat mekanisme pelaporan rutin setiap tahun yang dapat dipertanggungjawabkan.

\section{SIMPULAN DAN SARAN}

Temuan penelitian ini antara lain dana desa sebagai modal awal berdirinya BUMDes, sementara pemaknaan aktor atas tatakelola BUMDes dalam perspektif good governance government bahwa musdes sebagai bentuk partisipasi masyarakat, transparansi dimaknai dengan ketersediaan website desa dan grup whatsapp, serta belum berjalannya praktik akuntansi sebagai bentuk akuntabilitas keuangan. Penelitian ini secara teoritis memberikan pemahaman baru bagaimana pemaknaan konsep good governance government oleh para informan. Secara praktis implikasi dari penelitian ini adalah peningkatan pemahaman dan pelaksanaan konsep good governance government pada BUMDes. Keterbatasan penelitian ini adalah peneliti belum menggali lebih dalam bagimana dan mengapa praktik good governance government pada BUMDEs. Saran untuk penelitian selanjutnya adalah menggali secara natural bagaimana praktik tatakelola BUMDes dengan pendekatan grounded theory. Pendekatan ini diharapkan menemukan model tata kelola yang sesuai dengan karakteristik dan budaya masing-masing desa.

\section{DAFTAR RUJUKAN}

Agunggunanto, E. Y., \& Kushartono, E. W. (2016). Pengembangan Desa Mandiri Melalui Pengelolaan Badan Usaha Milik Desa (BUMDes). Jurnal Dinamika Ekonomi \& Bisinis, 13(1), 67-81. doi:10.34001/jdeb.v13i1.395.

Batubara, A. H. (2006). Konsep Good Governance dalam Konsep Otonomi Daerah. Jurnal Analisis Administrasi Dan Kebijakan, 3(1), 1-6.

Carter, A. J., Burritt, R. L., \& Pisaniello, J. D. (2013). The Dual Roles for Accountants in Sustaining Rural Communities. Accounting Research Journal, 26(2), 130-153. doi:10.1108/ARJ-12-2012-0093

Ismail, M., Widagdo, A. K., \& Widodo, A. (2016). Sistem Akuntansi Pengelolaan Dana Desa. Jurnal Ekonomi dan Bisnis, 19(2), 323-340. Doi: 10.24914/jeb.v19i2.236.

Kompas. (2019). Total Dana Desa 2019-2024 Rp400 Triliun.

Kurniasih, D., \& Wijaya, S. S. (2017). Kegagalan Bisnis Pemerintah Desa (Studi tentang Relasi BisnisPemerintah pada Pengelolaan Badan Usaha Milik Desa di Kabupaten Banyumas). Journal of Public Sector Innovations, 1(2), 66-72.

Kusumawanti, N., Susanti, A., \& Izana, N. N. (2017). Bumdes and Asean Economic Communities in Developing Rural Economy. International Conference Asean Golden Anniversary, 128-139.

Lindawati, A. S. L., \& Puspita, M. E. (2015). Corporate Social Responsibility: Implikasi Stakeholder dan Legitimacy Gap dalam Peningkatan Kinerja Perusahaan. Jurnal Akuntansi Multiparadigma, 6(1), 157-174. doi:10.18202/jamal.2015.04.6013.

Mansur. (2017). Implementasi Sistem Layanan Informasi Profil Desa melalui Media ONline untuk Meningkatkan Transparansi Informasi Desa. Jurnal Ilmiah Ilmu Komputer, 3(1), 22-27. doi:10.35329/jiik.v3i1.63.

Muslim. (2016). Varian-Varian Paradigma, Pendekatan, Metode, dan Jenis Penelitian dalam Ilmu Komunikasi. Wahana, 1(10), 77-85.

Mustanir, A., \& Abadi, P. (2017). Partisipasi Masyarakat dalam Musyawarah Rencana Pembangunan di Kelurahan Kanyuara Kecamatan Watang Sidenreng Kabupaten Sidenreng Rappang. Jurnal Politik Profetik, 5(2), 247-261. doi:10.24252/profetik.v4i2a6. 
Myers, M. D. 2009. Qualitative Research In Business And Management. London: Sage Publication.

Nahruddin, Z. (2014). Akuntabilitas dan Transparansi Pengelolaan Dana Alokasi Desa di Desa PaoPao Kecamatan Tanete Rilau Kabupaten Barru. Otoritas Jurnal Ilmu Pemerintahan, 4(2), 193201.

Prasetyo, R. A. (2016). Peranan Bumdes dalam Pembangunan dan Pemberdayaan Masyarakat di Desa Pejambon Kecamatan Sumberrejo Kabupaten Bojonegoro. Jurnal Dialektika, 11(1), 86100.

Ridlwan, Z. (2014). Urgensi Badan Usaha Milik Desa (BUMDes) dalam Pembangun Perekonomian Desa. Fiat Justisia, 8(3), 424-440. doi:10.25041/fiatjustisia.v8no3.314.

Suaramerdeka. (2018). Bumdes Kebonan Biayai Iuran BPJS Warga.

Triani, N. N. A., \& Handayani, S. (2018). Praktik Pengelolaan Keuangan Dana Desa. Jurnal Akuntansi Multiparadigma, 9(1), 136-155. doi:10.18202/jamal.2018.04.9009.

Widiastuti, H., Manuhara, W., \& Rahman, E. (2019). Menakar Tata Kelola Badan Usaha Milik Desa di Indonesia. Jurnal Ekonomi Dan Bisnis, 22(2), 257-288. doi:10.24914/jeb.v22i2.2410.

Yin, R., K. (2003). Case Study Research Design And Methods (Third Ed.). Thousand Oaks, C.A.: Sage Publications. 
Halaman ini sengaja dibiarkan kosong 